Apparatewesen E.V., held at Konigsberg on July 3-5 last, indicate that the object aimed at is the use of raw materials obtained in Germany in the manufacture of German goods. When a suitable material, native to that country, is not available, steps should be taken to enable other materials, found in Germany, to be adapted for the required purpose. Where, however, suitable substitutes cannot be found, investigations should be made with the view of constructing the plant or article using the minimum quantities of imported materials. No details regarding how these objects are to be attained are given, so that unless the original papers are studied, little more than an outline of the subjects considered can be obtained, the motto of the congress being "Nur deutsche Stoffe für deutsche Waren".

\section{Engineers' Study Group on Economics}

TमE Engineers' Study Group on Economics is entering its third year of activity, and Sir Richard Gregory has been elected president for the year. The Group consists of six sections investigating the various factors that may help to solve the present paradox of poverty amidst plenty. An analysis of twenty-four existing or proposed social and economic systems, prepared by Section B of the Group, was noticed in NATURE of May 25, 1935, p. 884. Section A, which is investigating the available, the desirable and the potential production of Great Britain, hopes to present a similar report shortly. Scientific workers, not necessarily engineers, willing to help in the application of scientific principles to the urgent problems of the day are welcomed by the Group. The yearly subscription is : minimum 5s., maximum f1. Sections meet in the evening at 85 Gloucester Place, W.1. The next group meeting will be at the Guildhouse, Eccleston Square, S.W.1 (Berwick Street entrance), on Tuesday, October 15, at 7 p.m.; Sir Richard Paget will speak on his recent visit to the U.S.S.R. Those wishing to attend should notify the honorary secretary, A. H. Hayes, Hazlitt House, Southampton Buildings, W.C.2 (Tel. : Holborn 1068).

\section{Tsetse Fly Control}

THE report of the East Africa Sub-Committee of the Tsetse Fly Committee, Economic Advisory Council (Cmd. 4951. London : H.M. Stationery Office. 1s. net), epitomises many factors bearing upon the problems of human sleeping sickness, as well as of tsetse fly diseases of animals, in Africa. Both diseases are caused by trypanosome parasites and are transmitted by tsetse flies, so that methods for eradication of the flies constitute important preventive measures. The most recent advance in this direction is by means of densification of the vegetation. It has been found that if a patch of tsetse-infested bush is protected from grass fires for several seasons, the growth becomes so dense as to be highly unfavourable to certain species of tsetse, and further investigation on these lines on a large scale is desirable.

\section{Therapeutic Substances}

The Joint Committee constituted under the Therapeutic Substances Act, 1925, has issued addi- tional regulations dealing with several agents, namely, staphylococcus toxoid, antipneumococcus serums (Types i and ii), staphylococcus antitoxin, gas-gangrene antitoxins and diphtheria prophylactic ("Statutory Rules and Orders 1935, No. 580"). The provisions applicable to these substances, which have now attained definite value in medical practice, include definition and proper name, labelling, quality, strength, and tests of potency, and unit of standardisation.

\section{Export of British Scientific Instruments to France}

Certain kinds of British optical and scientific instruments are subject to special quotas when im. ported into France. In order to ensure the full benefit of these quotas to British manufacturers, and to prevent the detention of shipments, the French Government has authorised the Scientific Instrument Manufacturers Association of Great Britain to issue certificates to shippers. The instruments to which these certificates apply are as follows:- simple surveying instruments; dividing machines; house barometers; apparatus for physical and chemical demonstration for schools and colleges; apparatus for physical and chemical researches and analyses; surveying instruments for geodesy, topography and measurements of angle. More precise information may be obtained from the Secretary, Scientific Instrument Manufacturers Association of Great Britain, Limited, 329 High Holborn, London, W.C.1.

\section{International Exhibition of Nature Photography}

The Right Hon. the Earl of Onslow, president of the Society for the Preservation of the Fauna of the Empire, will open an International Exhibition of Nature Photography in the Whale Hall of the British Museum (Natural History), South Kensington, on Wednesday, October 16 , at 12 noon. The object of the exhibition is to show the advance nature photography has made during recent years; and the exhibition should be of considerable interest and educational value. It will remain open every day from 10 a.m. until 6 p.m. (Sundays 2.30 p.m. until 6 p.m.) from October 16 to November 30. Admission is free. More than 1,200 photographs of birds and mammals will be shown, including examples from all British Colonies as well as from the United States, Poland, Japan, etc.

\section{French Congress of Hygiene}

THE twenty-second French Congress of Hygiene will be held at the Institut Pasteur, Paris, on October 21-23, when the chief subjects for discussion will be the hygiene and protection of infancy, and will be followed on October 23 by a meeting of the Société de la meteorologie médicale, an offshoot of the Société de medecine publique. Further information can be obtained from the general secretary, Dr. Dujarric de la Rivière, Institut Pasteur, rue Dutot, Paris.

\section{German Pharmacological Society}

THE German Pharmacological Society will hold its annual meeting at Munich on October 20-23, when 
the following subjects will be discussed: (1) water excretion of mammals and its physiological regulation, introduced by Verney of Cambridge; (2) the problem of the relation between chemical constitution and pharmacological therapeutic action, introduced by Schuleman of Elberfeld; (3) hynotics and basal narcosis, introduced by Weese of Elberfeld, Schon of Leipzig and Frey of Düsseldorf ; (4) pharmacology and clinical employment of circulatory stimulants, introduced by Hildebrandt of Giessen and Killian of Freiburg. Further information can be obtained from Prof. Janssen, Pharmacologisches Institut, Freiburg i. B., or the general secretary, Prof. B. Behrens, Dorotheenstrasse 28, Berlin.

\section{Announcements}

The Right Hon. J. Ramsay Macdonatd will open the Coal Hydrogenation Petrol Plant of Imperial Chemical Industries, Ltd., at Billingham. on-Tees, Durham, on October 15.

AN Exchange telegram from Copenhagen states that Prof. Niels Bohr, on his fiftieth birthday on October 7, was handed 100,000 kroner (nearly £4,000), which has been subscribed for among scientific societies in Denmark for the purchase of radium for research.

THE following appointments have recently been made by the Secretary of State for the Colonies : Mr. A. Pickles, to be entomologist, Department of Agriculture, Trinidad; Mr. J. W. Costello, late assistant conservator of forests, to be assistant conservator of forests, Nigeria; Mr. T. A. Strong, deputy conservator of forests, to be conservator of forests, Malaya; Mr. J. G. Watson, conservator of forests, to be deputy director of forests, Malaya.

A Broclimatic investigation department is to be established at Bad Pyrmont under the direction of Reg. Rat Lossnitzer, of Berlin.

AN institute for the biology of heredity and racial hygiene has been opened at Frankfurt-on-Main under the direction of Prof. Eugen Fischer.

The King of the Belgians has recently laid the first stone of a cancer institute bearing the name of Jules Bordet, in honour of the former director of the Pasteur Institute of Brussels. The Institute is attached to the new Hopital St. Pierre, Brussels.

A Power Farming Conference will be held in Oxford in January next under the auspices of the School of Rural Economy, the Institute for Research in Agricultural Engineering, and the Agricultural Economics Research Institute. The date provisionally fixed for the Conference is January 7-10.

During the recent International Congress of the History of Medicine at Madrid, the degree of doctor honoris causa was conferred at the ancient University of Alcala en Henares among others on Sir Humphry
Rolleston, the British delegate, and Profs. Neuburger of Vienna, Diepgen of Berlin, LaigneILavastine of Paris and Sigerist of Johns Hopkins, who occupy the chair of the history of medicine in their respective universities.

By courtesy of the Compagnie Générale Trans. atlantique, the Science Museum, South Kensington, has secured the loan of a fine model, more than ten feet in length, of the Normandie, the present holder of the Blue Riband of the Atlantic. The Normandie has a length of $1,029 \mathrm{ft}$., beam $119 \mathrm{ft}$., tonnage 79,280 , and turbo-electric machinery developing 160,000 horse-power. Her record-breaking run, New York to Plymouth, was accomplished in 4 days $3 \mathrm{hr}$. $25 \mathrm{~min}$. at an average speed of $30 \cdot 31$ knots.

Messers. A. Galdenkamp and Co., Ltd. (Technico House, Finsbury Square, London, E.C.2), have issued a revised edition of their catalogue "Apparatus for the Examination of Soil". The list includes the latest patterns and modifications of standard apparatus used in connexion with all types of soil work. Where desirable, directions for use are included, together with the appropriate bibliographical reference, so that direct contact with the scientific origin of the apparatus is possible.

Erratum.--In Prof. Karl Pearson's letter on "Statistical Tests" in NatuRE of October 5, p. 550, the values of the eccentricities $e$ should have been given in tenths, not hundredths; that is, $e=0.6$, not $0 \cdot 06$. This has no bearing on the argument.

Applications are invited for the following appointments, on or before the dates mentioned :

A research assistant in insect physiology in the Imperial College of Science, South Kensington, S.W.7 (Oct. 15).

A lecturer in mechanical engineering in the Birmingham Central Technical College-The Principal (Oet. 19).

A chemist in the Admiralty Chemical Pool-The Secretary of the Admiralty (C.E. Branch), Whitehall, London, S.W.1 (Oct. 25).

A junior assistant for the Directorate of Explosives Research-The Chief Superintendent, Research Department, Royal Arsenal, Woolwich, S.E.18 (Oct. 26).

A lecturer in mathematics in Goldsmiths' College -The Warden, Goldsmiths' College, New Cross, S.E.14 (Oct. 28).

A lecturer in physics in the University of Cape Town-The Secretary to the High Commissioner for the Union of South Africa, Trafalgar Square, London, W.C.2 (Nov. 5).

A virus physiologist at Rothamsted Experimental Station, Harpenden, Herts-The Secretary (Dec. 15).

An assistant lecturer in agriculture in the Midland Agricultural College, Sutton Bonnington, Loughborough--The Principal. 